[1-4]. In every case repeated amino acid stretches present in the proteins have been indicated to be the binding sites for tubulin. Similar (almost identical) sequences have been found for the tubulin binding site on MAP2 and tau, while a different tubulin binding motif has been observed in MAP1B. A main structural difference between both types of binding sequences is that the MAP2/tau sequence contains a high proportion of glycine and proline residues, ( $\alpha$-helix breakers), while the possible domains for tubulin interaction on MAP1B have the potential for forming an $\alpha$-helix (Fig. 1), as determined by the prediction methods of Chou-Fasman [5] and Garnier-Osguthorpe-Robson [6], and, also, as previously suggested by Noble et al. [4].

One important observation from these analyses is that the putative tubulin-binding $\alpha$-helices on MAP1B may have an amphipathic character. The helices show a polarity based on the difference between their two surfaces, one containing a high proportion of acidic residues and the other containing a high proportion of basic residues. The cationic surface of these $\alpha$ helices could bind to the $C$-terminal region of tubulin, a domain highly enriched in acidic amino acids which also has the potential to become an $\alpha$-helix (Fig. 1).

The $C$-terminal acidic sequence of tubulin had actually been described as the one involved in its binding to MAP1 peptides [7]. Thus it can be proposed that the binding of MAP1B to tubulin could take place by the ionic interaction of two $\alpha$-helices. However, the binding of MAP2 to tubulin has not the same structural constraints as the interaction between two $\alpha$-helices. It remains to be established whether these differences might have consequences for the polarity of microtubules, if brain MAPs are involved in microtubule nucleation in vitro, for example in the axonal growth cone or in dendrites. The fact that microtubules have uniform polarity in axons [8], in which MAP1 is a major constituent and MAP2 is nearly absent, whereas microtubules with opposite polarities are found within dendrites [8], in which MAP2 is a major constituent, might support this view.

\section{Jesus AVILA}

Centro de Biologí Molecular (CSIC-UAM), Universidad Autonóma, 28049 Madrid, Spain

1. Lewis, F. A., Wang, D. \& Cowan, N. J. (1988) Science 242, 936-939

2. Lee, G., Cowan, N. \& Kirschner, M. (1988) Science 239, 285-288

3. Goedert, M., Wischik, C., Crowther, R., Walker, J. \& Klug, A. (1988) Proc. Natl. Acad. Sci. U.S.A. 85, 4051-4055

4. Noble, M., Lewis, S. A. \& Cowan, N. J. (1989) J. Cell Biol. 109, 3367-3376

5. Chou, P. Y. \& Fasman, G. D. (1978) Annu. Rev. Biochem. 47, 251-276

6. Garnier, J., Osguthorpe, D. J. \& Robson, B. (1978) J. Mol. Biol. 120, $97-120$

7. Serrano, L., Montejo, E., Hernandez, M. A. \& Avila, J. (1985) Eur. J. Biochem. 153, 595-600

8. Baas, P. W., Deitch, J. S., Black, M. M. \& Banker, G. A. (1988) Proc. Natl. Acad. Sci. U.S.A. 85, 8335-8339

9. Wang, D., Villasante, A., Lewis, S. A. \& Cowan, N. J. (1986) J. Cell Biol. 103, 1903-1910

10. Schiffer, M. \& Edmudson, A. B. (1967) Biophys. J. 7, 121-130

Received 5 November 1990

\section{Inositol 1,4,5-trisphosphate 3-kinase activity in high-speed supernatants from rat pancreatoma cells, AR4-2J}

AR4-2J is a stable cell line derived from a rat pancreatoma which has been found to retain many of the functional

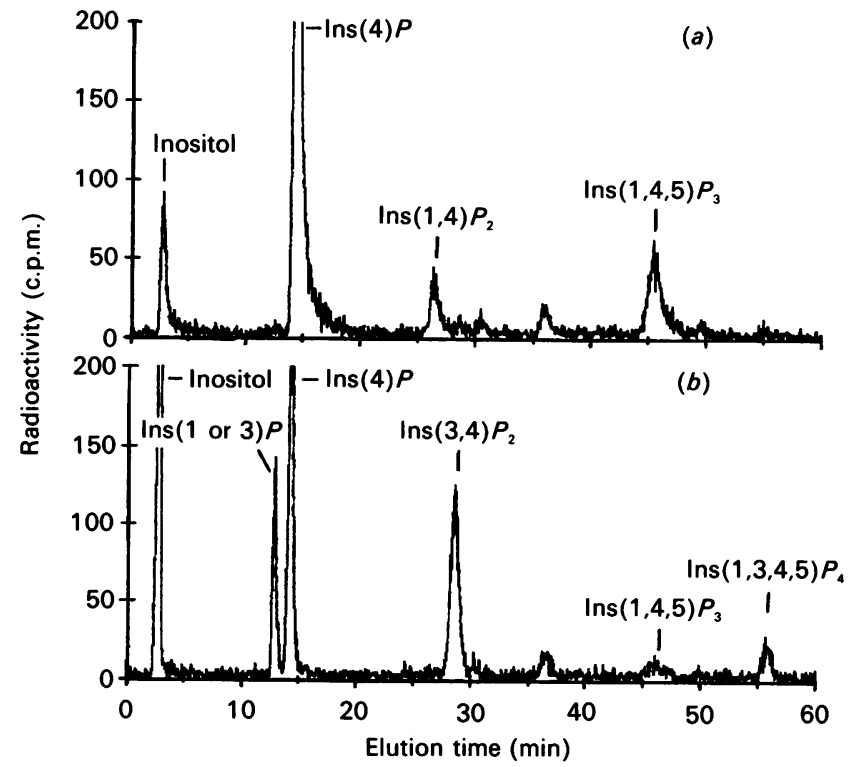

Fig. 1. $\left[{ }^{3} \mathrm{H}\right] \operatorname{Ins}(1,4,5) P_{3}$ metabolism in $A R 4-2 J$ cell homogenate and soluble subcellular fraction

Cell homogenate and soluble fraction were prepared in an intracellular-like solution containing ATP and an ATP-regenerating system (Horstman et al., 1988) and incubated with $\left[{ }^{3} \mathrm{H}\right] \operatorname{Ins}(1,4,5) P_{3}$ (100 $\mathrm{nm}$ final concentration). The duration of the incubations shown were $1 \mathrm{~min}$ for homogenate (panel $a$ ) and $5 \mathrm{~min}$ for soluble fraction (panel $b$ ). $\left[{ }^{3} \mathrm{H}\right] \operatorname{Ins}(1,4,5) \boldsymbol{P}_{3}$ and metabolites were determined by h.p.l.c. according to the method of Dean \& Moyer (1987) and Horstman et al. (1988). The unlabelled peak eluted at approx. 37 min was an unidentified contaminant present regardless of assay condition. Similar results were obtained in a separate experiment.

characteristics of pancreatic acinar cells (Longnecker et al., 1979; Jessop \& Hay, 1989; Womack et al., 1985). However, Horstman et al. (1988), in an investigation of $\operatorname{Ins}(1,4,5) P_{3}$ metabolism and $\mathrm{Ca}^{2+}$ mobilization after substance $P$ receptor stimulation, found that the formation of $\operatorname{Ins}(1,4,5) P_{3}$ was transient in these cells and that no Ins $(1,3,4,5) P_{4}$ accumulated. Furthermore, phosphorylation of $\operatorname{Ins}(1,4,5) P_{3}$ to $\operatorname{Ins}(1,3,4,5) P_{4}$ was not detected in AR4-2J cell homogenates. These results suggested that the AR4-2J cells may be deficient in the Ins $(1,4,5) P_{3}$ 3-kinase found in normal pancreas and other tissues. Subsequently, we have observed an accumulation of Ins $(1,3,4,5) P_{4}$ when AR4-2J cells were stimulated with bombesin (Nogimori et al., 1990; Menniti et al., 1990). It was suggested that the accumulation of Ins $(1,3,4,5) P_{4}$ after bombesin receptor stimulation, but not after substance $P$ receptor stimulation, is a consequence of differences in the efficacy and duration of response to these agonists (Nogimori et al., 1990; Menniti et al., 1990). Nevertheless, it is paradoxical that $\operatorname{Ins}(1,4,5) P_{3}$ 3-kinase activity was not previously detected in AR4-2J cell homogenates. This issue is resolved by the finding described below that the 3-kinase activity in AR4-2J cell extracts is unmasked during cell fractionation.

AR4-2J cell homogenates were prepared in an intracellularlike solution containing ATP and an ATP-regenerating system as described by Horstman et al. (1988). The final concentration of cell protein was $50-100 \mathrm{mg} / \mathrm{ml}$. Soluble and particulate fractions were prepared by centrifugation of homogenates at $100000 \mathrm{~g}$ (TLA 100.3 rotor in a Beckman mini-ultracentrifuge) for $1 \mathrm{~h}$ at $3^{\circ} \mathrm{C}$. Homogenate and subcellular fractions (each representing $100 \mu \mathrm{l}$ of original homogenate) were preincubated for $5 \mathrm{~min}$ at $37^{\circ} \mathrm{C}$ prior to addition of $20 \mu$ l of $\left[{ }^{3} \mathrm{H}\right] \operatorname{Ins}(1,4,5) P_{3}$ (sp. radioactivity $5.6 \mathrm{Ci} / \mathrm{mmol}$; NEN Research Products, E.I. du Pont de Nemours and Co., Boston, MA, U.S.A.) to initiate the reaction. 
The final $\left[{ }^{3} \mathrm{H}\right] \operatorname{Ins}(1,4,5) P_{3}$ concentration was $100 \mathrm{nM}$, adjusted by addition of non-radioactive $\operatorname{Ins}(1,4,5) P_{3}$ (Amersham Corp., Arlington Heights, IL, U.S.A.). Reactions were stopped after $1-5$ min by addition of $120 \mu \mathrm{l}$ of ice-cold $15 \%$ trichloroacetic acid containing $250 \mathrm{mg}$ of phytate. After a further incubation at $4{ }^{\circ} \mathrm{C}$ for $20 \mathrm{~min}$, precipitated protein was removed by centrifugation and the supernatants were neutralized by ether extraction as previously described (Horstman et al., 1988). The $\left[{ }^{3} \mathrm{H}\right]$ inositol phosphates in the neutralized samples were quantified by h.p.l.c. according to the method of Dean \& Moyer (1987) as previously described (Horstman et al. 1988).

In whole homogenates of AR4-2J cells, exogenous $\left[{ }^{3} \mathrm{H}\right] \operatorname{Ins}(1,4,5) P_{3}$ was dephosphorylated to $\left[{ }^{3} \mathrm{H}\right] \operatorname{Ins}(1,4) P_{2}$ and $\left[{ }^{3} \mathrm{H}\right]$ Ins(4) $P$ (Fig. 1a). As previously reported (Horstman et al., 1988), no $\left[{ }^{3} \mathrm{H}\right] \operatorname{Ins}(1,3,4,5) P_{4}$ or its metabolites were formed. This pattern of $\left[{ }^{3} \mathrm{H}\right] \operatorname{Ins}(1,4,5) P_{3}$ metabolism was similar in the particulate fraction (results not shown). However, $\left[{ }^{3} \mathrm{H}\right] \operatorname{Ins}(1,3,4,5) P_{4}$ was recovered after incubation of $\left[{ }^{3} \mathrm{H}\right] \operatorname{Ins}(1,4,5) P_{3}$ with the supernatant fraction (Fig. $1 b)$. The $\left[{ }^{3} \mathrm{H}\right] \operatorname{Ins}(1,3,4,5) P_{4}$ formed was further metabolized to $\left[{ }^{3} \mathrm{H}\right] \operatorname{Ins}(3,4) P_{2}$, and both $\left[{ }^{3} \mathrm{H}\right] \operatorname{Ins}(1$ or 3)- and (4)P; $\left[{ }^{3} \mathrm{H}\right] \operatorname{Ins}(1,3,4) P_{3}$ did not accumulate. These findings are consistent with a cytosolic localization for the Ins $(1,4,5) P_{3}$ 3-kinase in AR4-2J cells, as found in other tissues (Irvine et al., 1986; Shears, 1989).

Although previous and present results now indicate that the AR4- $2 \mathrm{~J}$ cells contain an Ins $(1,4,5) P_{3} 3$-kinase, it has been pointed out that the agonist-stimulated accumulation of $\operatorname{Ins}(1,3,4,5) P_{4}$ in intact AR4-2J cells is very low as compared to non-tumour acinar cells (Nogimori et al., 1990; Menniti et al., 1990). In addition to the previously raised possibility, that these cells express only low levels of the $\operatorname{Ins}(1,4,5) P_{3}$ 3-kinase (Horstman et al., 1988), the AR4-2J cells may over-express the 5-phosphatase which degrades $\operatorname{Ins}(1,4,5) P_{3}$ to $\operatorname{Ins}(1,4) P_{2}$. Alternatively, the 3-kinase may be chronically inhibited in the AR4-2J cells. These latter suggestions stem from the present finding that 3-kinase activity was readily detected only in the soluble fraction prepared from these cells. This unmasking of 3-kinase activity may result from a purification away from an endogenous inhibitor of the enzyme or a separation from phosphatase activities which compete for Ins $(1,4,5) P_{3}$ substrate in the assay of the homogenate fraction. Resolution of these various possibilities may shed light on the regulation of this component of $\operatorname{Ins}(1,4,5) P_{3}$ metabolism in this cell line as well as in non-tumour acinar cells.

Frank S. MENNITI and James W. PUTNEY, Jr.

Calcium Regulation Section, Laboratory of Cellular and Molecular Pharmacology, National Institute of Environmental Health Sciences, National Institutes of Health, Research Triangle Park, NC 27709, U.S.A.

Dean, N. M. \& Moyer, J. D. (1987) Biochem. J. 242, 361-366

Horstman, D. A., Takemura, H. \& Putney, J. W., Jr. (1988) J. Biol. Chem. 263, 15297-15303

Irvine, R. F., Letcher, A. J., Heslop, J. P. \& Berridge, M. J. (1986) Nature (London) 320, 631-634

Jessop, N. W. \& Hay, R. J. (1989) In Vitro 16, 212

Longnecker, D. S., Lilja, H. S., French, J. I., Kuhlmann, E. \& Noll, W. (1979) Cancer Lett. 7, 197-202

Menniti, F. S., Oliver, K. G., Nogimori, K., Obie, J. F., Shears, S. B. \& Putney, J. W., Jr. (1990) J. Biol. Chem. 265, 11167-11176

Nogimori, K., Menniti, F. S. \& Putney, J. W., Jr. (1990) Biochem. J. 269, 195-200

Shears, S. B. (1989) Biochem. J. 260, 313-324

Womack, M. D., Hanley, M. R. \& Jessel, T. M. (1985) J. Neurosci. 5, 3370-3378

Received 19 November 1990 